\title{
ANALISIS RISIKO INVESTASI DEPOSITO MUDHARABAH (Studi pada Bank Syariah Mandiri Tahun 2013-2015)
}

\author{
Ulul Azmi Musthofa, Iin Emy Prastiwi \\ STIE AAS Surakarta \\ Email:ulul.azmi@yahoo.com
}

\begin{abstract}
Value at Risk is defined as an estimate of the maximum loss of an investment over a given period and a given confidence level. The purposes of this research is to understand the size of financial risk and net return of mudharabah deposit on Islamic bank using Value at Risk (VaR) approach.

Objects of this research is quarterly financial report of Bank Syariah Mandiri, for three years, 2013-2015. VaR analysis shows that investment mudaraba deposits at Bank Syariah Mandiri as measured by VaR approach to investment risk (VaRmean) in 2013 amounted to $0.30 \%$, and a net return of $0.54 \%$, in 2014 the mean VaR $0.18 \%$, and the net return $0.62 \%$, in 2015 the mean VaR of $0.25 \%$, and a net return of $0.55 \%$.
\end{abstract}

Keywords : Value at Risk ( VaR ), risk, net return, mudharabah deposit

\section{PENDAHULUAN}

Islam mendorong umatnya untuk memproduktifkan hartanya untuk kegiatan ekonomi. Menurut Machmud (2010:147) ada dua hal aktivitas keuangan dalam Islam yang dipandang sebagai wahana bagi masyarakat modern, yaitu (1) saling membantu dan bekerja sama dalam masyarakat untuk kebaikan, dan (2) menghindari dari kegiatan menahan uang, membiarkannya menganggur (idle), dan tidak berputar dalam transaksi yang bermanfaat. Jadi, dalam ajaran Islam melarang umatnya mengumpulngumpulkan harta, menyimpannya saja tanpa aktivitas ekonomi apapun.

Jika seseorang merasa tidak mampu memproduktifkan hartanya dalam kegiatan ekonomi, maka seseorang bisa melakukan cara investasi. Harta tersebut bisa diinvestasikan kepada perdagangan, perusahaan-perusahaan, pasar modal, perbankan, dan lain-lain. Seorang investor, selain keuntungan yang diharapkan, jaminan keamanan dan kehalalan bentuk usaha menjadi hal yang tidak boleh dipandang sebelah mata. Investasi yang sesuai syariat Islam adalah yang mempunyai manfaat, dan terhindar dari hal-hal yang dilarang, seperti riba, gharar, dan maisir. Oleh karena itu, tak sedikit orang memili investasi pada Perbankan Syariah berbentuk investasi deposito mudharabah. Selain keuntungan, jaminan keamanan juga ada, dimana bank syariah berada dibawah pengawasan Bank Indonesia. Untuk jaminan kehalalan usaha juga ada, yaitu bank syariah dalam operasionalnya dibawah pengawasan DSNMUI. 
Setiap investasi pasti ada keuntungan (return) dan risiko (risk). Dalam berinvestasi, segala sesuatu harus direncanakan, dipersiapkan, dan diprediksi sematang mungkin untuk menghindari risiko. Sebagaimana dalam firman-Nya $\mathrm{Al}$ Qur'an surat Al Hasyr (59) ayat 18 "hai orang-orang yang beriman, bertakwalah kepada Allah dan hendaklah setiap diri memperhatikan apa yang telah diperbuatnya untuk hari esok (akhirat)" Allah memerintahkan umatnya untuk merencanakan dan mempersiapkan apa yang akan terjadi di hari esok. Pengamalan ayat ini bisa diterapkan dalam berinvestasi.

Risiko dalam investasi tidak harus selalu dihindari, tetapi sesuatu yang harus dipelajari, diprediksi, dan dipersiapkan secara matang sehingga menghasilkan high return sesuai yang diharapkan.

\section{INVESTASI DEPOSITO MUDHARABAH}

Menurut Prabowo (2009:91) menjelaskan jenis investasi dasar dalam pandangan Islam yang termasuk produk penghimpunan dana (funding) perbankan syariah selain giro dan tabungan adalah deposito. Sedangkan menurut fatwa Dewan Syariah Nasional Nomor 03/DSNMUI/IV/2000 menyatakan bahwa deposito yang dibenarkan adalah deposito yang berdasarkan prinsip mudharabah (Karim, 2010:351)

Menurut Al Anshori (2009) produk deposito karena memang ditujukan sebagai sarana investasi, maka digunakan akad mudharabah dalam prakteknya. Melalui akad mudharabah ditentukan berapa nisbah bagi hasil baik pihak nasabah maupun pihak bank syariah sendiri diawal perjanjian. Menurut Sumitro (2010: 35)
Investasi deposito mudharabah yaitu simpanan yang penarikannya hanya dapat dilakukan pada waktu tertentu menurut perjanjian antara penyimpan dengan bank yang bersangkutan dengan menerapkan sistem bagi hasil keuntungan.

\section{BAGI HASIL PADA BANK SYARIAH}

Dalam sistem ekonomi Islam, bunga dapat dinyatakan sebagai riba yang "haram" hukumnya menurut syariah Islamiyah. Sebagai gantinya, sistem ekonomi Islam menggantinya dengan pranata "bagi hasil" yang dihalalkan oleh syariah Islamiyah berdasarkan Al Qur'an dan Al Hadits. Dalam praktiknya, ketentuan bagi hasil usaha harus ditentukan dimuka pada awal akad/ kontrak usaha disepakati oleh pihak-pihak yang terlibat dalam akad (Wiyono, 2005:56-57).

Dalam praktiknya, mekanisme perhitungan bagi hasil dapat didasarkan pada dua cara profit sharing (bagi hasil) dan revenue sharing (bagi pendapatan). Perhitungan bagi hasil menurut profit sharing adalah perhitungan bagi hasil yang berdasarkan pada laba dari pengelola dana, yaitu pendapatan usaha dikurangi dengan beban usaha untuk mendapatkan pendapatan usaha tersebut. Sedangkan perhitungan bagi hasil menurut revenue sharing adalah perhitungan bagi hasil berdasarkan pada revenue (pendapatan) dari pengelola dana, yaitu pendapatan usaha sebelum dikurangi dengan beban usaha untuk mendapatkan pendapatan usaha tersebut.

\section{Rate of Return / Indikasi Equivalent Rate}

Rate of return adalah tingkat pengembalian bersih atas modal/investasi atau dana yang disimpan di perbankan. 
Pada bank konvensional rate of return dipersamakan dengan bunga bank. Adapun perhitungan rate of return adalah sebagai berikut (Wiyono, 2005: 6970):

$$
\mathrm{RR}=\underline{\mathrm{BBH}} \times \frac{\text { setahun }}{\text { SRRH }} \times 100 \%
$$

Keterangan :

$\mathrm{RR} \quad=$ rate of return

$\mathrm{BBH}=$ bonus dan bagi hasil

$\mathrm{SRRH}=$ saldo rata-rata harian dana pihak ke tiga

\section{MANAJEMEN RISIKO PERBANKAN SYARIAH}

Dalam dunia perbankan, manajemen risiko menjadi hal penting dalam operasional perbankan. Transaksi keuangan yang menimbulkan risiko biasanya adalah pemberian kredit dan yang menimbuklan resiko credit (credit risk) dan adanya simpanan dari pihak ketiga menimbulkan risiko likuiditas (liquidity risk). Risiko dapat didefinisikan sebagai volatilitas outcome yang umumnya berupa nilai dari suatu aktiva atau hutang (Ghozali, 2007: 3).

Menurut Lina Nur Hidayati, Risiko dapat dikatakan sebagai suatu peluang terjadinya kerugian atau kehancuran. Lebih luas risiko dapat diartikan sebagai kemungkinan terjadinya hasil yang tidak diinginkan atau berlawanan dari yang diinginkan. Risiko dapat menimbulkan kerugian apabila tidak diantisipasi serta tidak dikelola dengan semestinya. Sebaliknya risiko yang dikelola dengan baik akan memberikan ruang pada terciptanya peluang untuk memperoleh suatu keuntungan yang lebih besar.

Menurut El Tiby (2011), Perbankan syariah akan menghadapi 2 tipe risiko dalam pelaksanaanya, yaitu:

- Risiko yang sama dengan bank konvensional (risk similar to conventional banks)

- Risiko yang unik dan khusus (unic and specific risks). Risiko ini muncul dalam kaitan dengan kebutuhan tertentu, yang diperlukan untuk mematuhi prinsipprinsip syariah.

Ada banyak risiko yang dihadapai perbankan. Perbankan harus mempunyai strategi menghadapi risiko-risiko yang mungkin terjadi, oleh karena itu perbankan harus mempunyai manajemen risiko. Manajemen risiko meliputi perencanaan strategis dan perencanaan modal, manajemen aset-liabilitas, dan manajemen risiko bisnis serta keuangan sebuah bank. Komponen utama dari manajemen risiko adalah identifikasi, kuantifikasi, dan pemantauan profil risiko, termasuk risiko perbankan dan keuangan (Van Greuning, 2011: 63).

Sebagai lembaga intermediary dan seiring dengan situasi lingkungan eksternal dan internal perbankan akan mengalami perkembangan pesat, bank syariah akan selalu berhadapan dengan berbagai jenis risiko dengan tingkat kompleksitas yang beragam dan melekat pada kegiatan usahanya. Risiko dalam konteks perbankan merupakan suatu kejadian potensial, baik yang dapat diperkirakan (anticipated) maupun yang tidak dapat diperkirakan (unaticipated) yang berdampak negatif terhadap pendapatan dan permodalan bank. Risiko-risiko tersebut tidak dapat dihindari, tetapi dapat dikelola dan dikendalikan. Oleh karena itu sebagaimana lembaga perbankan pada umumnya, bank syariah juga memerlukan serangkaian prosedur 
dan metodologi yang dapat digunakan untuk mengidentifikasi, mengukur, memantau, dan mengendalikan risiko yang timbul dari kegiatan usaha atau yang biasa disebut sebagai manajemen risiko (Karim, 2010 : 255).

Manajemen risiko muncul sebagai jawaban terhadap semakin meningkatnya volatilitas pasar uang global sebagai akibat dari teknologi. Perkembangan pada teori keuangan modern memungkinkan bagi institusi keuangan untuk menciptakan harga dan pengendalian risiko terhadap instrument keuangan baru. (Ghozali, 2007 : 5)

Menurut Karim (2010:255) tujuan manajemen risiko itu sendiri adalah sebagai berikut:

- Menyediakan informasi tentang risiko kepada pihak regulator.

- Memastikan bank tidak mengalami kerugian yang bersifat unacceptable

- Meminimalkan kerugian dari berbagai risiko yang bersifat uncontrolled

- Mengukur eksposur dan pemusatan risiko

- Mengalokasikan modal dan membatasi risiko

Secara umum, risiko-risiko yang melekat pada aktivitas fungsional bank syariah dapat diklasifikasikan kedalam tiga jenis risiko, yaitu (Karim, 2010 : 260):

- Risiko Pembiayaan (Financing Risk) adalah risiko yang disebabkan adanya kegagalan counterparty dalam memenuhi kewajibannya.

- Risiko Pasar (Market Risk) adalah perubahan nilai aset bersih karena perubahan dalam faktor-faktor ekonomi seperti suku bunga, nilai tukar, harga saham dan harga komoditi. Risiko pasar mencakup:
Risiko Tingkat Suku Bunga

(Interest Rate Risk), Risiko

Pertukaran Mata Uang (Foreign

Exchange Risk), Risiko Harga

(Price Risk), dan Risiko Likuiditas

(Liquidity Risk).

- Risiko Operasional (Operational Risk) adalah risiko yang antara lain disebabkan oleh ketidakcukupan atau tidak berfungsinya proses internal, human error, kegagalan sistem atau adanya problem eksternal yang mempengaruhi operasional bank. Risiko ini mencakup: Risiko Reputasi (Reputation Risk), Risiko Kepatuhan (Complian Risk), Risiko Strategik (Strategic Risk), Risiko Transaksi (Transactional Risk), Risiko Hukum (Legal Risk)

\section{KONSEP STATISTIK TENTANG MANAJEMEN RISIKO}

Risiko mempunyai dua komponen utama yaitu ketidakpastian (uncertainty) dan eksposure. Secara statistik risiko merupakan volatilitas dari sesuatu dapat berupa pendapatan, laba, biaya dan sebagainya. Volatilitas merupakan ukuran dispersi (penyebaran) yang dalam statistik diukur dengan variance $\left({ }^{2}\right)$ atau standar deviasi (). Semakin besar nilai variance atau standar deviasi, maka semakin besar risikonya (Ghozali, 2007:55).

\section{a. Return}

Menurut Ghozali (2007: 55), return adalah pendapatan yang akan diterima jika kita menginvestasikan uang pada suatu aktiva finansial (saham, obligasi) atau aktiva riil (property, tanah). Return saham dapat dihitung harian, mingguan, bulanan, dan tahunan. 
Semakin pendek periodenya misalkan harian maka semakin baik perhitungan return menggunakan geometri yang memberikan continuously compound return.

Berdasarkan data pengamatan ini kita dapat menentukan besarnya expected return (Er) saham Telkom dengan rumus (Ghozali, 2007: 55-58):

$$
E r=\frac{\sum_{\mathrm{i}=\rfloor}^{\mathrm{N}} \mathrm{ri}}{\mathrm{N}}
$$

\section{b. Risiko (Risk)}

Variasi besarnya return harian selama pengamatan sering disebut dengan volatilitas. Volatilitas merupakan ukuran risiko. Secara statistik volatilitas diukur dengan variance $\left(\sigma^{2}\right)$ dan standar deviasi $(\sigma)$. Rumus perhitungan variance $\left(\sigma^{2}\right)$ dan standar deviasi $(\sigma)$ sebagai berikut:

$$
\begin{aligned}
& \text { variance }\left(\sigma^{2}\right)= \\
& \frac{\sum_{\mathrm{I}=]^{N}}^{\mathrm{N}}(\mathbf{r i}-\mathrm{Er}) 2}{N-1} \\
& \text { satndar deviasi } \\
& =\sqrt{\frac{\sum_{\mathrm{i}=\mathrm{l}^{\mathrm{N}}(\mathbf{i}-\mathrm{Er}) 2}^{N-1}}{N-1}}
\end{aligned}
$$

Keterangan:

ri = return saham berdasarkan pengamatan sampel

$\mathrm{Er}=$ expected return saham (nilai rata-rata return)

$\mathrm{N}=$ jumlah observasi dan pengamatan

Semakin besar nilai variance atau standar deviasi maka menunjukkan semakin berisiko investasi tersebut (Ghozali, 2007: 59$60)$.

\section{c. Value at Risk (VaR)}

Salah satu teknik pengukuran risiko adalah Value at Risk (VaR). Menurut Ghozali (2007:6) VaR dapat didefinisikan: "VaR measures the worst expected loss over a given horizon under normal market conditions at a given confidence level. Jadi VaR dapat diartikan ukuran kerugian terburuk yang diharapkan akan terjadi pada horizon waktu tertentu pada kondisi pasar yang normal dengan tingkat kepercayaan tertentu. Banyak institusi keuangan dan regulator melirik VaR sebagai metode yang mudah untuk memahami dan mengkuantifikasikan risiko pasar.

Menurut Ihsan (2012:361), VaR adalah estimasi kerugian maksimum yang akan dialami sebuah investasi selama periode waktu tertentu pada tingkat kepercayaan tertentu. Menurut Van Greuning (2008:210) VaR adalah teknik permodelan yang biasanya mengukur pemaparan risiko pasar keseluruhan dari suatu bank dan mengingat tingkat probabilitasnya, mengestimasi jumlah kerugian yang akan dialami bank jika ingin memiliki aset tertentu untuk suatu periode waktu tertentu.

Menurut JP Morgan dalam Value at Risk: An Overview of analytical VaR "VaR is a predictive (ex-ante) tool used to prevent portfolio managers from exceeding risk tolerances that have been developed in the portfolio policies. It can be measured at the portfolio, sector, asset class, and security level". VaR adalah alat prediksi yang digunakan untuk mencegah dan mengatur risiko portofolio, agar tidak melebihi toleransi risiko yang telah dikembangkan dalam 
kebijakan portofolio.

Statistik VaR memiliki tiga komponen yaitu: periode waktu, tingkat kepercayaan (confidence level) dan jumlah kerugian (atau kerugian dalam prosentase). Berikut tabel tingkat kepercayaan (confidence level) untuk VaR:

Tabel 1

Tingkat Kepercayaan (Confidence Level)

\begin{tabular}{|c|c|}
\hline Confidence & \# of Standar Defiation $(\sigma)$ \\
\hline $95 \%$ (high) & $-1.65 \times \sigma$ \\
\hline $95 \%$ (really high) & $-2.33 \times \sigma$ \\
\hline
\end{tabular}

Sumber : D. Harper, 2004 yang dikutip oleh Prabowo (2009: 97)

Nilai kepercayaan $95 \%$ memberikan nilai faktor (confidence factor) 1,65 dengan asumsi distribusi normal, begitu juga tingkat kepercayaan $99 \%$ memberikan nilai faktor 2,33. Jika diketahui bahwa standar deviasi dari distribusi return harian saham adalah $\sigma$, maka besarnya VaR dapat dihitung dengan rumus Ghozali (2007: 79):

\section{$\mathrm{VaR}=$ Confidence faktor $\mathrm{x}$}

\section{Standar deviasi}

Ada tiga metode perhitungan VaR yaitu: metode historis, metode variancecovariance dan metode simulasi Monte de Carlo (Ghozali, 2007: 75-81)

\section{1) Metode Historis}

Metode historis menggunakan data historis dan menyusun data historis tersebut dengan urutan dari terjelek ke terbaik. Metode historis pada prinsipnya kita mengorganisasikan data return harian saham dalam bentuk histogram dan menyusunnya dengan urutan dari return terburuk ke return terbaik. Kemudian kita berasumsi bahwa sejarah akan berulang dilihat dari perspektif risiko.

\section{2) Metode Variance-covariance}

Metode ini mengasumsikan bahwa return saham memiliki distribusi normal (normal distributed) dengan demikian kita hanya akan memerlukan estimasi dua faktor yaitu expected return (rata-rata return) dan standar deviasi return.

3) Metode Simulasi Monte Carlo

Metode ini mengembangkan sebuah model return saham QQQ dimasa datang dengan cara simulasi. Simulasi Monte de Carlo merupakan metode mendapatkan angka return secara random. Simulasi adalah model untuk melakukan imitasi terhadap kehidupan sesungguhnya atau melakukan peramalan (Ghozali, 2007: 79-80). 
Gambar 1

Kerangka Berpikir

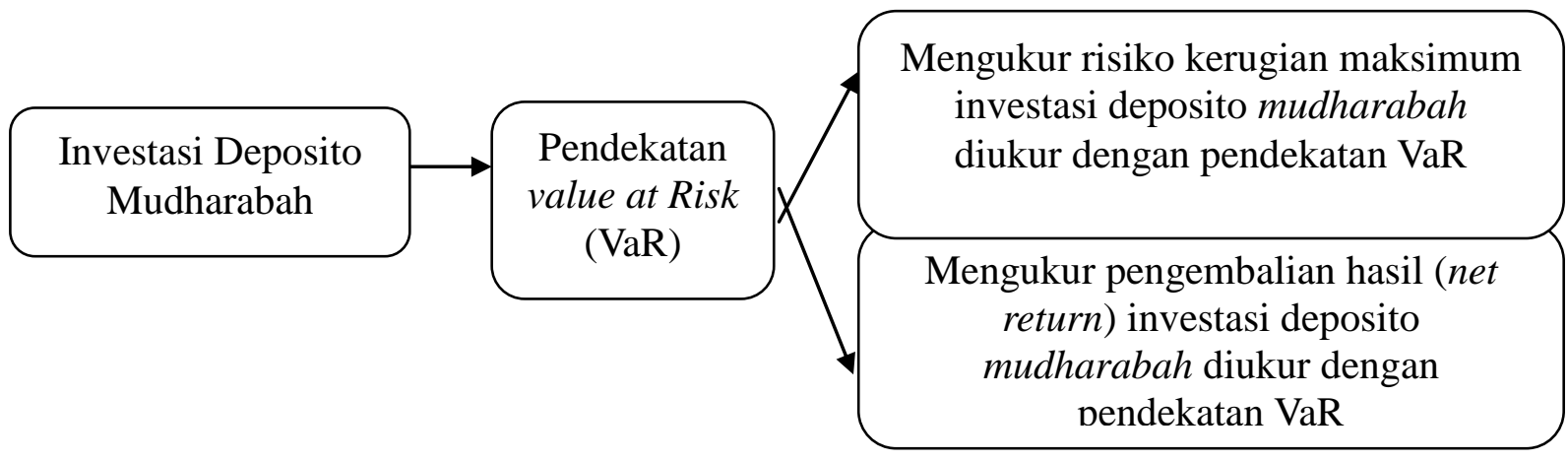

Dalam penelitian ini, jenis investasi yang akan diteliti adalah investasi deposito mudharabah menggunakan alat analisis Value at Risk (VaR), yaitu seberapa besar potensi kerugian maksimal investor (deposan) dalam investasi deposito mudharabah selama horizon waktu $t$ (setahun) dengan tingkat kepercayaan tertentu (confidence level). Selain itu Value at Risk (VaR) juga mengukur berapa pengembalian hasil (net return) yang ditawarkan oleh perbankan syariah.

\section{METODE PENELITIAN}

\section{Jenis Penelitian}

Metode penelitian dalam penelitian ini menggunakan penelitian empiris kuntitatif. Metodologi ini menggambarkan analisis statistik dimana untuk mengetahui bobot risiko dan pengembalian hasil (net return) investasi deposito mudharabahdi bank syariah dengan menggunakan pendekatan Value at Risk (VaR).

Dalam hal ini peneliti akan melakukan penelitian di Bank Mandiri Syariah, dan usulan penelitian tahun 2013-2015. Data kuntitatif dalam penelitian ini terdiri dari masing- masing Laporan Keuangan Publikasi triwulan Bank Mandiri Syariah, tahun periode 2013-2015. Data meliputi jumlah investasi deposito mudharabah, dan distribusi pendapatan bagi hasil deposito mudharabah. Data yang didapat untuk dianalisis risiko dan pengembalian hasil (net return) mudharabah dengan metode VaR.

\section{Alat Anlisa}

Alat analisa dalam penelitian ini menggunakan Value at Risk (VaR). Metodologi ini menggambarkan analisis statistik dimana untuk mengetahui bobot risiko dan pengembalian hasil (net return) investasi di Bank Mandiri Syariah.

Metode Pendekatan Value at Risk (VaR) dapat dijelaskan sebagai berikut:

1) Metode pengukuran risiko dihitung dengan estimasi prosentase kerugian potensial melalui VaR nilai absolut dan nilai relatif. Nilai VaR absolut adalah kerugian terhadap zero (nol) dan nilai VaR relatif adalah kerugian yang dibandingkan dengan rata-rata 
nilai pengembalian hasil yang

dilihat dengan formulasi diharapkan (expected return). sebagai berikut:

Estimasi pendekatan VaR dapat

\begin{tabular}{|ll|}
\hline $\operatorname{VaR}($ mean $)$ & $=\mathrm{A} 0 \alpha \sigma \sqrt{T}$ \\
\hline $\operatorname{VaR}($ zero & )
\end{tabular}

Sumber : Metode Pengukuran VaR, Prabowo (2009:97)

Dimana:

A0 :Menunjukkan jumlah nilai yang dinvestasikan pada tingkat pengembalian hasil (rate of return) deposito mudharabah,

$\alpha \quad$ :Menunjukkan distribusi standar normal,

$\sigma$ :Menunjukkan standar deviasi,

$\mathrm{T}$ :Menunjukkan selang waktu dimana ditentukan dalam tahun, (sehingga dalam tiga bulan menjadi 3/12) dan

$\mu \quad$ :Menunjukkan tingkat pengembalian hasil yang diharapkan (expected return).

2) VaR absolute dan $\mathrm{VaR}$ relative menggunakan metode parametrik yang dikalikan dengan dua parameter kuantitatif yaitu tingkat kepercayaan (confidence level) dan horizon waktu disebabkan sifat pengukurannya adalah estimasi. Tingkat kepercayaan didasarkan pada nilai distribusi standar normal $(\alpha)$ yang dapat dicari dari tabel kurva normal sebesar 1,65 untuk tingkat kepercayaan (c)95\% dan 2,33 untuk tingkat kepercayaan 99\%. Mengukur VaR lebih baik menggunakan tingkat kepercayaan yang lebih tinggi. Berbagai macam tingkat kepercayaan memberikan informasi yang berguna mengenai distribusi tingkat pengembalian hasil (return) dan kerugian esktrim potensial.

\begin{tabular}{|l|l|}
\multicolumn{1}{|c|}{ Confidence } & $\begin{array}{l}\text { \# of Standard } \\
\text { Deviations }(\omega)\end{array}$ \\
\hline $95 \%$ (high) & $-1.65 \times \sigma$ \\
\hline $99 \%$ (really high) & $-2.33 \times \sigma$ \\
\hline
\end{tabular}

Sumber : D.Harper, tahun 2004, dikutip oleh Yudho Prabowo (2009: 97) 
3) Tingkat pengembalian hasil yang diharapkan (expected return) digunakan untuk mengukur rata-rata estimasi atau perkiraan dari distribusi probabilitas yang diperoleh dari pendapatan nilai bagi hasil (return) deposito mudharabah.

Standar deviasi menunjukkan bahwa jika semakin besar standar deviasi dari pengembalian hasil, maka semakin besar variabel dari pengembalian hasil dan semakin tinggi risiko dari investasi tersebut. Dalam aplikasi penelitian ini, risiko investasi deposito mudharabah dapat dilihat secara total (total risk) melalui standar deviasi.

Dimana standar deviasi mengukur persentase ukuran jarak atau fluktuasi dari variabel rata-rata nilai pengembalian hasil yang diharapkan. Pada aplikasinya, standar deviasi adalah jumlah kuadrat variabel nilai equivalent rate (distribusi pendapatan bagi hasil deposito mudharabah) (Xi) dikurangi variabel nilai rata-rata (mean) equivalent rate bagi hasil deposito mudharabah (Xi) dibagi jumlah periode waktu (N) triwulanan dalam setahun, yaitu tahun 2010-2012 (Prabowo, 2009: 98)

\section{ANALISIS DAN PEMBAHASAN}

Penelitian ini membahas analisis risiko investasi deposito mudharabah menggunakan pendekatan analisis VaR. Menurut Prabowo (2009:101) hubungan nilai Gross Expected Return dengan dengan VaR (mean) dan VaR (zero) adalah sebagai berikut:

a. Nilai prospektif, apabila terdapat return yang besar dengan risiko yang kecil (low risk high return)

b. Nilai wajar, apabila terdapat return yang besar dengan risiko yang besar (high risk high return) atau terdapat return yang kecil dengan risiko yang kecil (low risk low return).

c. Nilai potensi kerugian, apabila terdapat return yang kecil dengan risiko yang besar (high risk low return).

VaR (zero) merupakan selisih dari $\mathrm{VaR}$ (mean) dengan gross expected return. Nilai VaR (zero) dapat dijelaskan sebagai berikut:

a. Nilai VaR (zero) positif dan signifikan berarti terdapat potensi kerugian investasi deposito mudharabah di Bank Syariah Mandiri. VaR (zero) bernilai positif apabila VaR (mean) bernilai lebih besar dari gross expected return.

b. Nilai VaR (zero) negatif dan signifikan berarti terdapat potensi profitabilitas investasi deposito mudharabah di Bank Syariah Mandiri. VaR (zero) bernilai negatif apabila VaR (mean) bernilai lebih kecil dari gross expected return.

Berdasarkan penjelasan diatas , makadapat diuraikan hasil analisis risiko investasi deposito mudharabah berjangka (1,3,6 dan 12 bulan) pada Bank Syariah Mandiri tahun 2013-2015 menggunakan pendekatan analisis VaR adalah sebagai 
berikut:

Tabel 2

Hasil Perhitungan VaR Mean dan Net Return Deposito Mudharabah

Bank Syariah Mandiri Tahun 2013-2015

\begin{tabular}{|c|c|c|c|c|}
\hline & & \multicolumn{3}{|c|}{ Bank Syariah Mandiri } \\
\hline & & 2013 & 2014 & 2015 \\
\hline Expected Return & $\mu$ & 0,033397105 & 0,031790384 & 0,032079883 \\
\hline Standar Deviasi & $\sigma$ & 0,002540108 & 0,001499019 & 0,002162029 \\
\hline VaR mean & $\mathrm{AO} \alpha \sigma \sqrt{T}$ & 0,002959225 & 0,001746357 & 0,002518764 \\
\hline Gross expected return & $\mathrm{AO} \mu T$ & 0,008349276 & 0,007947596 & 0,008019971 \\
\hline VaR zero & $\mathrm{AO}(\alpha \sigma \sqrt{T}-\mu T)$ & $-0,005390051$ & $-0,006201239$ & $-0,00550121$ \\
\hline Net Return & $\begin{array}{l}\text { Gross Expected } \\
\text { return- VaR mean }\end{array}$ & 0,005390051 & 0,0062012 & 0,005501207 \\
\hline
\end{tabular}

Sumber: Data sekunder diolah, 2016

Berdasarkan tabel 2 diatas, rata-rata nilai gross expected return terhadap equivalent rate deposito mudharabah berjangka (1,3,6 dan 12 bulan) cukup stabil, karena volatilitas VaR mean dan VaR zero lebih rendah daripada gross expected return. Investasi deposito mudharabah di Bank Syariah Mandiri cenderung menguntungkan karena VaR zero bernilai negatif.

Variasi besarnya return harian selama selama pengamatan disebut volatilitas. Volatilitas merupakan ukuran risiko, yang secara statistik volatilitas diukur dengan variance $\left(\sigma^{2}\right)$ atau standar deviasi $(\sigma)$. Standar deviasi digunakan

Gambar 2

Diagram VaR mean dan Net Return

Investasi Deposito Mudharabah Bank Syariah Mandiri

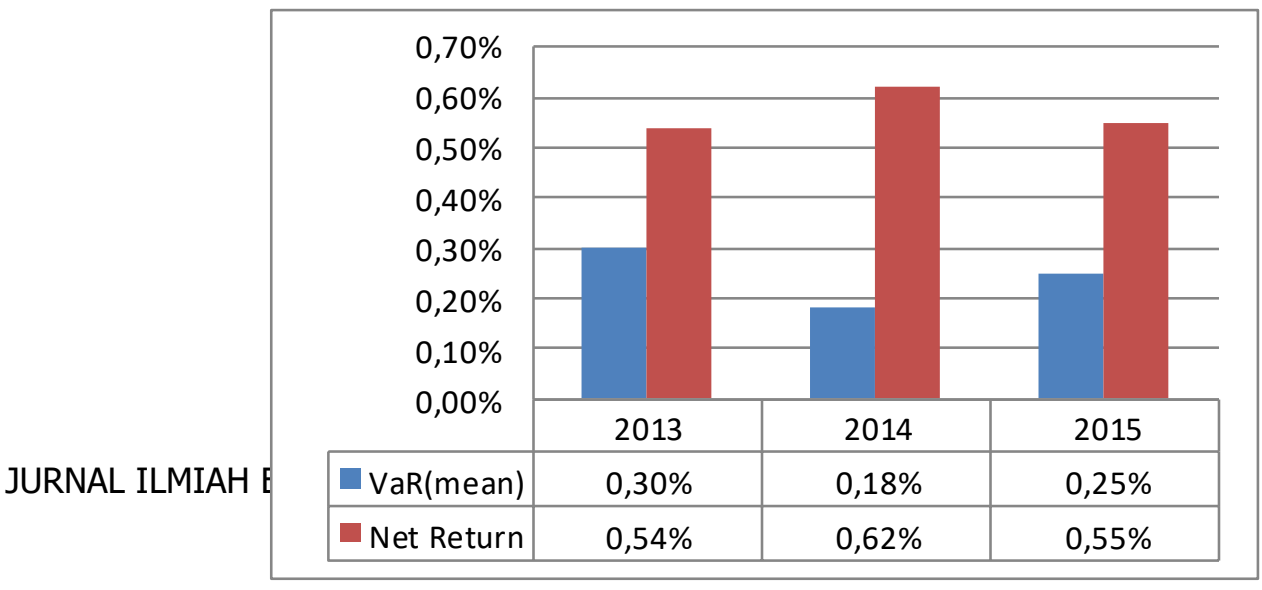

untuk mengukur prosentase ukuran jarak atau fluktuasi dari variabel rata-rata nilai pengembalian hasil yang diharapkan. Semakin besar standar deviasi dari return, maka semakin tinggi risiko dari investasi risiko tersebut (Ghozali, 2007:55-59). Return yang digunakan dalam penelitian ini adalah return triwulanan.

Berikut ditampilkan grafik hasil perhitungan menggunakan pendekatan VaR Bank Syariah Mandiri tahun 2013 sampai 2015. 
Berdasarkan gambar 2 diatas, Bank Syariah Mandiri tahun 2014 memiliki tingkat risiko

paling rendah yaitu $0,18 \%$ dengan net return paling tinggi $0,62 \%$ daripada tahun 2013 dan 2015. Hal ini menurut laporan keuangan triwulan Bank Syariah Mandiri tahun 2014 mengalami return yang lebih stabil. Hal ini berarti tahun 2014 Bank Syariah Mandiri mampu memberikan bagi hasil kepada investor deposito mudharabah yang lebih tinggi dan lebih stabil.

\section{KESIMPULAN}

Berdasarkan hasil perhitungan return investasi deposito mudharabah yang dilakukan selama tiga tahun berturut-turut pada Bank Syariah Mandiri, maka dapat disimpulkan bahwa investasi deposito mudharabah di Bank Syariah Mandiri setelah diukur dengan pendekatan VaR mempunyai risiko investasi (VaRmean) tahun 2013 sebesar $0,30 \%$, dan net return sebesar $0,54 \%$, pada tahun $2014 \mathrm{VaR}$ mean sebesar $0,18 \%$, dan net return sebesar $0,62 \%$, pada tahun $2015 \mathrm{VaR}$ mean sebesar $0,25 \%$, dan net return sebesar $0,55 \%$.

\section{DAFTAR PUSTAKA}

Al Anshori, Abdul ghofur. (2009). Trend Pembentukan Bank Umum Syari'ah Pasca Undang-Undang Nomor 21 Tahun 2008 :Konsep, Regulasi, dan Implementasi. Yogyakarta: BPFEYOGYAKARTA

El Tiby, Amr Mohammed. (2011) ISLAMIC BANKING: How To
Manage Risk and Improve Profitability. USA: Wiley Finance

Ghozali, Imam. (2007) Manajemen Risiko Perbankan: Pendekatan Kuantitatif Value at Risk (VaR). Semarang: Badan Penerbit Universitas Diponegoro

Karim, Adiwarman. A. (2010), Bank Islam Analisis Fiqh dan Keuangan. Jakarta: PT Raja Grafindo Persada. Edisi ke empat

Hidayati, Lina Nur, Mengukur Resiko Perbankan dengan VaR (Value at Risk)

Ihsan, Ibnuhardi Faizaini, at al. 2012. Pengukuran Value at Risk dengan Metode Variance-Covariance. Jurnal Jurusan Matematika, Fakultas Matematika dan Ilmu Pengetahuan Alam, Universitas Sebelas Maret, hlm 361-366

Machmud, Amir dan H. Rukmana. (2010). Bank Syariah: Teori, Kebijakan, dan Studi Empiris di Indonesia. Jakarta: Penerbit Erlangga

Prabowo, Yudha. (2009). Analisis Risiko dan Pengembalian Hasil pada Perbankan Syariah : Aplikasi Metode VaR dan RAROC pada Bank Syariah Mandiri. Jurnal Ekonomi Islam. Vol. III.no 1.hlm 90-105

Sumitro, Warkum. (2004). Asas-asas 
Perbankan Islam dan Lembagalembaga Terkait. Jakarta: PT Raja Grafindo Perkasa

Van Greuning, Hennie and Sonja Brajovic B. (2008) Analisis Risiko Perbankan
Syari'ah, (Terjemahan). Jakarta : Salemba Empat

www.syariahmandiri.co.id 